\title{
Tonic Activation of Bax Primes Neural Progenitors for Rapid Apoptosis through a Mechanism Preserved in Medulloblastoma
}

\author{
Andrew J. Crowther, ${ }^{1 *}$ Vivian Gama, ${ }^{6 *}$ Ariana Bevilacqua, ${ }^{4}$ Sha X. Chang, ${ }^{2,5}$ Hong Yuan, ${ }^{3,5}$ Mohanish Deshmukh, ${ }^{4,5,6}$ \\ and Timothy R. Gershon ${ }^{1,4,5}$ \\ Departments of ${ }^{1}$ Neurology, ${ }^{2}$ Radiation Oncology, and ${ }^{3}$ Radiology, ${ }^{4}$ Neuroscience Center, ${ }^{5}$ Lineberger Comprehensive Cancer Center, and ${ }^{6}$ Department of \\ Cell Biology and Physiology, University of North Carolina School of Medicine, Chapel Hill, North Carolina 27599
}

Commitment to survival or apoptosis within expanding progenitor populations poses distinct risks and benefits to the organism. We investigated whether specialized mechanisms regulate apoptosis in mouse neural progenitors and in the progenitor-derived brain tumor medulloblastoma. Here, we identified constitutive activation of proapoptotic Bax, maintained in check by Bcl-xL, as a mechanism for rapid cell death, common to postnatal neural progenitors and medulloblastoma. We found that tonic activation of Bax in cerebellar progenitors, along with sensitivity to DNA damage, was linked to differentiation state. In cerebellar progenitors, active Bax localized to mitochondria, where it was bound to Bcl-xL. Disruption of Bax:Bcl-xL binding by BH3-mimetic ABT 737 caused rapid apoptosis of cerebellar progenitors and primary murine medulloblastoma cells. Conditional deletion of Mcl-1, in contrast, did not cause death of cerebellar progenitors. Our findings identify a mechanism for the sensitivity of brain progenitors to typical anticancer therapies and reveal that this mechanism persists in medulloblastoma, a malignant brain tumor markedly sensitive to radiation and chemotherapy.

\section{Introduction}

Stem cells and progenitor cells are expanding populations that rigorously calibrate survival decisions. We have recently demonstrated that embryonic stem (ES) cells regulate apoptosis through a specialized mechanism in which proapoptotic Bax is constitutively activated and sequestered in the Golgi compartment (Dumitru et al., 2012). This mechanism eliminates stem cells with DNA damage. Brain progenitors, like stem cells, have the potential to propagate mutations caused by genotoxic injury. We therefore examined whether specialized mechanisms regulate neural progenitor apoptosis.

Cerebellar granule neuron progenitors (CGNPs) proliferate rapidly in the postnatal period to give rise to the most numerous neuronal population in the brain, the cerebellar granule neurons (CGNs; Miale and Sidman, 1961; Roussel and Hatten, 2011). Importantly, CGNPs are specifically vulnerable to malignant transformation, giving rise to medulloblastoma, the most com-

\footnotetext{
Received June 19, 2013; revised Sept. 16, 2013; accepted 0ct. 3, 2013

Author contributions: T.R.G., A.J.C., V.G., A.B., S.X.C., H.Y., and M.D. designed research; A.J.C., V.G., and A.B. performed research; T.R.G., A.J.C., V.G., S.X.C., H.Y., and M.D. analyzed data; T.R.G., A.J.C., V.G., and M.D. wrote the paper.

T.R.G. is supported by grants from the National Institutes of Health (NIH; 1K08NS077978-01), the St. Baldrick's Foundation, the Morgan Adams Foundation, the American Institute for Cancer Research, and the Matthew Larson Brain Tumor Foundation. This project is supported in part by NIH Grants NS042197 and GM078366 to M.D. We thank the UNC Tissue Pathology Laboratory for expertise in immunohistochemistry.

*V.G. and A.J.C. contributed equally to this work.

The authors declare no competing financial interests.

Correspondence should be addressed to Dr. Timothy R. Gershon, Department of Neurology, CB 7025, UNC School of Medicine, Chapel Hill, NC 27599. E-mail: gershont@neurology.unc.edu.

DOI:10.1523/JNEUROSCI.2602-13.2013

Copyright $\odot 2013$ the authors $\quad 0270-6474 / 13 / 3318098-11 \$ 15.00 / 0$
}

mon malignant brain tumor of children (Grimmer and Weiss, 2006). Apoptosis (Garcia et al., 2013), in concert with p27mediated differentiation (Miyazawa et al., 2000; Ayrault et al., 2009; Bhatia et al., 2010; Parathath et al., 2010), control the CGNP population growth and suppress tumorigenesis.

CGNPs are markedly prone to apoptosis in response to a variety of stimuli. Exposure of the cerebellum to ionizing radiation induces CGNP cell death through processes involving Atm, Bax, and p53 (Chong et al., 2000). Replication stress can also trigger CGNP apoptosis, as demonstrated by the population-wide death of CGNPs after deletion of Atr (Lee et al., 2012). CGNP apoptosis can also be triggered independent of p53, through systemic administration of glucocorticoid agents (Noguchi et al., 2008; Heine and Rowitch, 2009).

The vulnerability of CGNPs has important clinical implications. The sensitivity of CGNPs to DNA damage is recapitulated in medulloblastoma, which is strikingly responsive to therapies that cause genotoxic injury. Indeed, $>80 \%$ of patients are cured through radiation combined with chemotherapy (Packer et al., 2006). Conversely, the proapoptotic effect of steroids on CGNPs can complicate the care of premature infants who are commonly treated with glucocorticoid agents and are at high risk for impaired motor development (Hitzert et al., 2012; ter Wolbeek et al., 2013). Thus, mechanisms that regulate apoptosis in CGNPs impact both tumor treatment and brain development.

Bax and Bak are proapoptotic Bcl-2 family proteins that act as essential triggers of the apoptotic program (Tait and Green, 2010). In most cells, Bax is present in an inactive, monomeric form that remains in the cytoplasm (Hsu et al., 1997). With the induction of apoptosis, Bax undergoes a conformational change 
that leads to its oligomerization and translocation to the outer mitochondrial membrane. Thus activated, Bax induces mitochondrial outer membrane permeabilization (MOMP), the first committed step in the apoptotic process (Wolter et al., 1997; Antonsson et al., 2001). Importantly, the conformational change that mediates Bax activation exposes an amino acid motif that is recognized by monoclonal antibody 6A7, enabling the detection of Bax activation by immunoprecipitation (IP; Hsu and Youle, 1997). Here, we report that brain progenitors harbor tonically active Bax at mitochondria, facilitating rapid induction of cell death in response to diverse proapoptotic stimuli.

\section{Materials and Methods}

Generation of mice. The breeding and genotyping of $\mathrm{Bax}^{-1-}$ mice have been described previously (Knudson et al., 1995). Math-1 cre mice were generously shared by David Rowitch (University of California, San Francisco, San Francisco, CA) and Robert Wechsler-Reya (Sanford-Burnham Medical Research Institute, La Jolla, CA) and have been previously described (Matei et al., 2005). hGFAP-cre mice were generously provided by Eva Anton (University of North Carolina, Chapel Hill, NC); these mice express cre during brain development in stem cells that give rise to diverse progeny, including the entire cerebellum (Zhuo et al., 2001). Mcl- $1{ }^{\mathrm{f} / \mathrm{f}}$ mice were generously shared by You-Wen He (Duke University, Durham NC). SmoM2 mice (strain:5130), p53-1- mice (strain:2101), and $\mathrm{Bax}^{\mathrm{f} / \mathrm{f}} ; \mathrm{Bak}^{-1-}$ mice (strain:6329) were obtained from Jackson Laboratories. Medulloblastoma-prone NeuroD2:SmoA1 mice were kindly provided by James Olson (Fred Hutchinson Cancer Research Center, Seattle, WA; Hallahan et al., 2004). All mice stated previously were inbred into the C57 BL/6 background. Wild-type ICR mouse pups were used for in vivo and CGNP experiments. Genotypes were determined by PCR: DNA was extracted from toes using Tail Lysis Buffer (Allele, cat\#ABPPP-MT01). Mice of either sex were used in experiments. All animal handling and protocols were performed in accordance with established practices as described in the National Institutes of Health Guide for Care and Use of Laboratory Animals and as approved by the Animal Care and Use Committee of the University of North Carolina (IACUC\# 10-126).

CGNP culture. Primary cultures of CGNPs from ICR mice were generated according to published protocols (Kenney et al., 2003). When indicated, CGNPs were maintained continuously in Sonic Hedgehog (Shh; $0.5 \mu \mathrm{g} / \mathrm{ml}$; R\&D Systems). In some experiments CGNGPs continuously maintained in Shh were also treated with $10 \mu \mathrm{M}$ of the Mek inhibitor U0126 for $24 \mathrm{~h}$ before harvest.

For radiation studies, CGNPs were cultured for $48 \mathrm{~h}$, then subjected to 10Gy using an x-ray irradiator (RS 2000, Rad Source Technologies); cells were immediately returned to the $\mathrm{CO}_{2}$ incubator and subsequently lysed after a defined period of time as indicated. Nonradiated cells were harvested concurrently with the $4 \mathrm{~h}$ samples.

In vivo steroid exposure. For these studies, P7 ICR pups were injected intraperitoneally with $50 \mu \mathrm{l}$ of Hanks buffered saline, with or without Dexamethasone (250 $\mu$ m; Sigma, cat\#D9184). Cerebella were harvested after $4 \mathrm{~h}$ and processed for Western blot as described below.

In vivo external beam radiation treatment. Mouse pups at $\mathrm{P} 9$ or tumorbearing pups at P12 were administered continuous anesthesia (Isoflurane, $1.5 \%$ ) for 4 min inside a small animal research irradiator (RS 2000, Rad Source Technologies) delivering x-ray irradiation to a total dose of $10 \mathrm{~Gy}$. The brain was selectively radiated by shielding the animal with an elevated lead plate with a 1-cm-wide opening positioned over the posterior fossa. Mice were heated and monitored while recovering from anesthesia and returned to a holding cage. Tissue was collected for histology by drop fixing in $4 \%$ formaldehyde for $24 \mathrm{~h}$.

Western blot analysis. Cultured cells, whole cerebella, and tumors were lysed by homogenization in lysis buffer (Cell Signaling Technology, cat\#9803). Protein concentrations were quantified using the bicinchoninic acid method (Thermo Scientific, cat\#23227) and equal concentrations of protein were resolved on SDS-polyacrylamide gels, then transferred onto PVDF membranes. Immunologic analysis was performed on a SNAP ID device (Millipore) using manufacturer's protocol with primary antibodies to $\beta$-actin (Cell Signaling Technology, cat\#4970), Bax-N20 (Santa Cruz Biotechnology, sc-493), Bcl-XL (Cell Signaling Technology, cat\#2764), Bad (Cell Signaling Technology, cat\#9239), Bim (Cell Signaling Technology, cat\#2933), Puma (Cell Signaling Technology, cat\#7467), cleaved caspase-3 (cC3; Cell Signaling Technology, cat\#9664), Cyclin D2 (Cell Signaling Technology, \#3741), Cox4 (Clontech, Cat. No. 630105), and p53 (Cell Signaling Technology, cat\#2524), Mcl-1 (Cell Signaling Technology, cat\#5453), Bcl-2 (Cell Signaling Technology, cat\#3498), and phospho-ERK1/2 (Cell Signaling Technology, cat\#4370). Secondary antibodies were anti-rabbit IgG HRP (Cell Signaling Technology, cat\#7074) and anti-mouse IgG HRP (Cell Signaling Technology, cat\#7076). Antibody conjugates were visualized by chemiluminescence (ECL; GE Healthcare, cat\#RPN2106).

Immunohistochemistry. For histological analysis and immunohistochemistry (IHC), mouse brain and tumor tissue were embedded in paraffin and sectioned. H\&E-stained sections were prepared using standard techniques. IHC was performed on paraffin-embedded sections after deparaffinization in Histoclear and rehydration in a graded ethanol series, heated to boiling in $10 \mathrm{~mm}$ citrate buffer, $\mathrm{pH}$ 6.0, in a pressure cooker for $15 \mathrm{~min}$, then transferred to PBS. After antigen retrieval, IHC was performed using primary antibodies: proliferating cell nuclear antigen (PCNA, Cell Signaling Technology, cat\#2586), cC3 (Cell Signaling Technology, cat\#9664), and phosphorylated histone H2AX (p-H2AX, Cell Signaling Technology, cat\#9718). Where indicated, nuclei were counterstained with 4'6-diamino-2-phenylindole (DAPI; catalog number D1306; Life Sciences), diluted $200 \mathrm{ng} / \mathrm{ml}$ in PBS for $5 \mathrm{~min}$. Immunofluorescence was evaluated with a Leica epifluorescence DM5000B microscope (Leica Microsystems). Stained slides were then scanned using an Aperio ScanScope XT.

Immunoprecipitation. For detecting the active form of Bax, tissues or cells were lysed in CHAPS buffer containing protease inhibitors. IP was performed by incubating $200 \mu \mathrm{l}$ of a $5 \mu \mathrm{g} / \mu \mathrm{l}$ lysate with $40 \mu \mathrm{l}$ of protein G Sepharose, preabsorbed with $2 \mu \mathrm{g}$ of anti-Bax monoclonal antibody (clone 6A7, BD-PharMingen) at $4^{\circ} \mathrm{C}$ for $2 \mathrm{~h}$. After extensive washing with CHAPS buffer, beads were boiled in $40 \mu \mathrm{l}$ of Laemmli buffer, and $20 \mu \mathrm{l}$ of the eluted proteins were analyzed by Western blotting. Western blotting analysis of pre-IP (labeled Input) and immunoprecipitated samples (labeled IP) were performed with an anti-Bax polyclonal antibody (Santa Cruz Biotechnology, Bax N-20, sc-493).

For detecting interaction of $\mathrm{Bcl}-\mathrm{xL}$ with active $\mathrm{Bax}$ or $\mathrm{BH} 3$-only proteins, tissues or cells were lysed in CHAPS buffer containing protease inhibitors. Four micrograms of antibody, either Bax6A7 or Bcl-xL (Cell Signaling Technology, cat\#2764), were cross-linked to Sepharose beads using disuccinimidyl suberate following the manufacturer's instructions (Pierce, Cat\#26147). Two-hundred microliters of a 10 $\mu \mathrm{g} / \mu \mathrm{l}$ lysate were added to the cross-linked antibody beads followed by incubation by $2 \mathrm{~h}$. After elution of the interaction complexes, Western blot analysis was performed with Bax (N20), Bcl-XL, Bad, Bim, or Puma antibodies.

Fractionation. CGNPs in the presence or absence of Shh (as described previously) were plated into 6-well dishes for $48 \mathrm{~h}$ before the experiments. When indicated, CGNPs were then subjected to 10Gy using an $\mathrm{x}$-ray irradiator and immediately returned to the $\mathrm{CO}_{2}$ incubator for $2 \mathrm{~h}$ before fractionation. The mitochondrial and cytosolic fractions were prepared using an Apo-Alert cell fractionation kit from BD Biosciences Clontech. Equal amounts of protein were loaded for Western blot analysis with Bax and Cox4 or Bcl-xL and Cox4.

BH3 mimetic exposure. An uncoated cell culture plate was equilibrated at $37^{\circ} \mathrm{C}, \mathrm{CO}_{2} 5 \%$ with each well containing an adequate volume of DMEM/F12 (Invitrogen, cat\#11330-032) supplemented with $1 \%$ N2(Life Technologies, cat $\# 17502048$ ), $1 \% \mathrm{KCl}$, and $5 \%$ fetal bovine serum at the indicated concentration of ABT 737 (Selleck Chemicals, cat $\#$ S1002) or DMSO. Final DMSO concentration was $<1 \%$. Cerebellum at $\mathrm{P} 6$ or $\mathrm{P} 11$ or tumor at $\mathrm{P} 12$ were quickly dissected and then dissociated in ice-cold HBSS by repeated trituration with pipette. Cell suspension was passed through a $40 \mu \mathrm{m}$ cell strainer (Fisher Scientific, cat\#22363547) and centrifuged at $100 \mathrm{rcf}$ for $3 \mathrm{~min}$. Supernatant HBSS was removed and the cell pellet was resuspended in media and applied in equal volumes to prepared plate. At $1 \mathrm{~h}$, each well was gently stirred and total volume of cell suspension was collected and centrifuged at $100 \mathrm{rcf}$. 

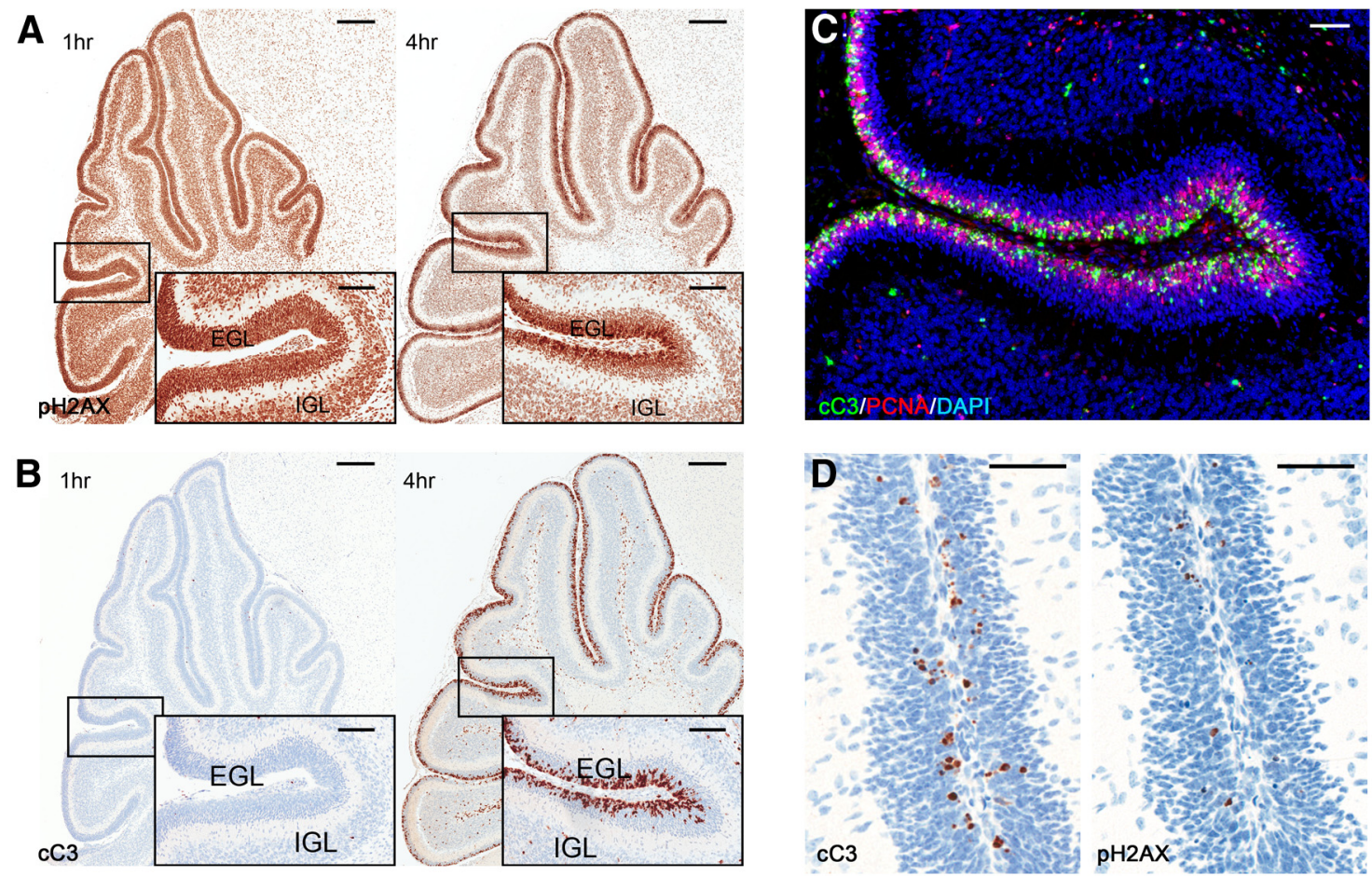

Figure 1. CGNPs adhere to a consistent schedule of rapid apoptosis after injury. $\boldsymbol{A}$, Radiation, administered as $10 \mathrm{~Gy}$ xRT focused on the posterior fossa, induced DNA damage in CGNPs of the EGL and CGNs of the IGL that was detectable by IHC for pH2AX at both 1 and $4 \mathrm{~h}$. B, Apoptosis, demonstrated by $\mathrm{C} C 3$, was undetectable during the latent period after xRT ( $1 \mathrm{~h}$ ), then began precipitously by $4 \mathrm{~h}$. C, Immunofluorescence for $\mathrm{CC} 3$ (green) and PCNA (red) demonstrates that apoptosis was confined to the proliferative layer of the EGL. $\boldsymbol{D}$, Corticosteroids induced apoptosis (CC3) without genotoxic injury (pH2AX). Scale bars: $A, B, 250 \mu \mathrm{m} ; A, B$ (insets) $100 \mu \mathrm{m} ; C, D, 50 \mu \mathrm{m}$.

Supernatant media was removed and cell pellet was lysed for protein analysis.

\section{Results}

CGNPs adhere to a rapid, consistent schedule of cell death in response to genotoxic and nongenotoxic stress

To determine the temporal sequence of apoptosis in CGNPs after diverse types of injury, we compared the kinetics of cell death after genotoxic or nongenotoxic stimulus. We provoked apoptosis through DNA damage by subjecting P9 mouse pups to $10 \mathrm{~Gy}$ external beam radiation treatment (xRT) focused on the posterior fossa. We then analyzed cerebella at progressive intervals after xRT. We found that radiation induced widespread DNA damage that was detectable in all neurons and progenitors by IHC for p-H2AX $1 \mathrm{~h}$ later (Fig. 1A). Following a brief, but consistently maintained period of latency, apoptosis began synchronously by 4 h exclusively in the external granule call layer (EGL), the location of CGNPs, as demonstrated by IHC for cC3 (Fig. 1B). This precipitous wave of cell death was restricted to a proliferating subset of CGNPs that populate the outer segment of the EGL (Fig. 1C).

To induce apoptosis without DNA damage, we subjected P7 mouse pups to corticosteroid injection. Dexamethasone has been previously reported to induce CGNP cell death $4 \mathrm{~h}$ after intraperitoneal injection (Noguchi et al., 2008; Heine and Rowitch, 2009). We confirmed that CGNP death proceeded $4 \mathrm{~h}$ after stimulus and demonstrated that apoptosis proceeded without induction of p-H2AX (Fig. 1D). Thus, CGNPs demonstrated a rapid apoptotic response with a consistent temporal onset after different types of injury.

The timing of cell death after injury was also recapitulated with remarkable fidelity in primary murine medulloblastoma. To examine the kinetics of cell death in medulloblastoma, we bred
Math1-cre (Matei et al., 2005) and SmoM2(Mao et al., 2006) mouse lines. In the resulting Math1-cre:SmoM2 pups, a constitutively active allele of Smoothened (SmoM2) is induced through cre-mediated recombination in the Math1-lineage, which in the cerebellum is restricted to the CGNPs and CGNs. These mice synchronously develop medulloblastoma with $100 \%$ incidence (Mao et al., 2006; Schüller et al., 2008), detectable by P12 as a characteristic expansion of the occipital region. Histologic analysis demonstrated replacement of the entire EGL with growing tumor in which scattered cells undergo spontaneous apoptosis (Fig. 2A, inset). We subjected tumor-bearing mice at P12 to $10 \mathrm{~Gy}$ $\mathrm{xRT}$ and then monitored the induction of DNA damage and cell death. We found that in tumors, as in the EGL, DNA damage was already detectable $1 \mathrm{~h}$ after treatment, while cell death increased precipitously by $4 \mathrm{~h}$ (Fig. $2 \mathrm{~B}, \mathrm{C}$ ). Thus, in vivo CGNPs and medulloblastoma cells adhered to a rapid, consistent schedule of cell death after injury.

\section{Bax is the principal death effector in CGNPs and is not complemented by Bak}

To identify the molecular mechanism of rapid CGNP death, we compared the response to xRT of CGNPs deficient in Bax, Bak, or both Bax and Bak. We bred and then radiated P9 mouse pups with genotypes $\mathrm{Bax}^{+/-} ; \mathrm{Bak}^{+/+}$(Bax het), $\mathrm{Bax}^{+/+} ; \mathrm{Bak}^{-/-}$(Bak $\mathrm{KO}), \mathrm{Bax}^{-l-} ; \mathrm{Bak}^{+/+}$(Bax KO), and hGFAP-cre;Bax ${ }^{\mathrm{fl} / \mathrm{fl}} ; \mathrm{Bak}^{-/-}$ (double $\mathrm{KO}$ ). We found that Bax deletion greatly reduced CGNPs apoptosis after xRT, while Bak deletion had minimal effect, and codeletion of Bax and Bak completely blocked xRT-induced cell death (Fig. $3 A-D$ ). Importantly, these findings demonstrate that neural progenitor death after $\mathrm{xRT}$ is apoptotic in nature, and does not result from any property of dividing cells unrelated to the apoptotic machinery. Moreover, these findings demonstrate that 
A

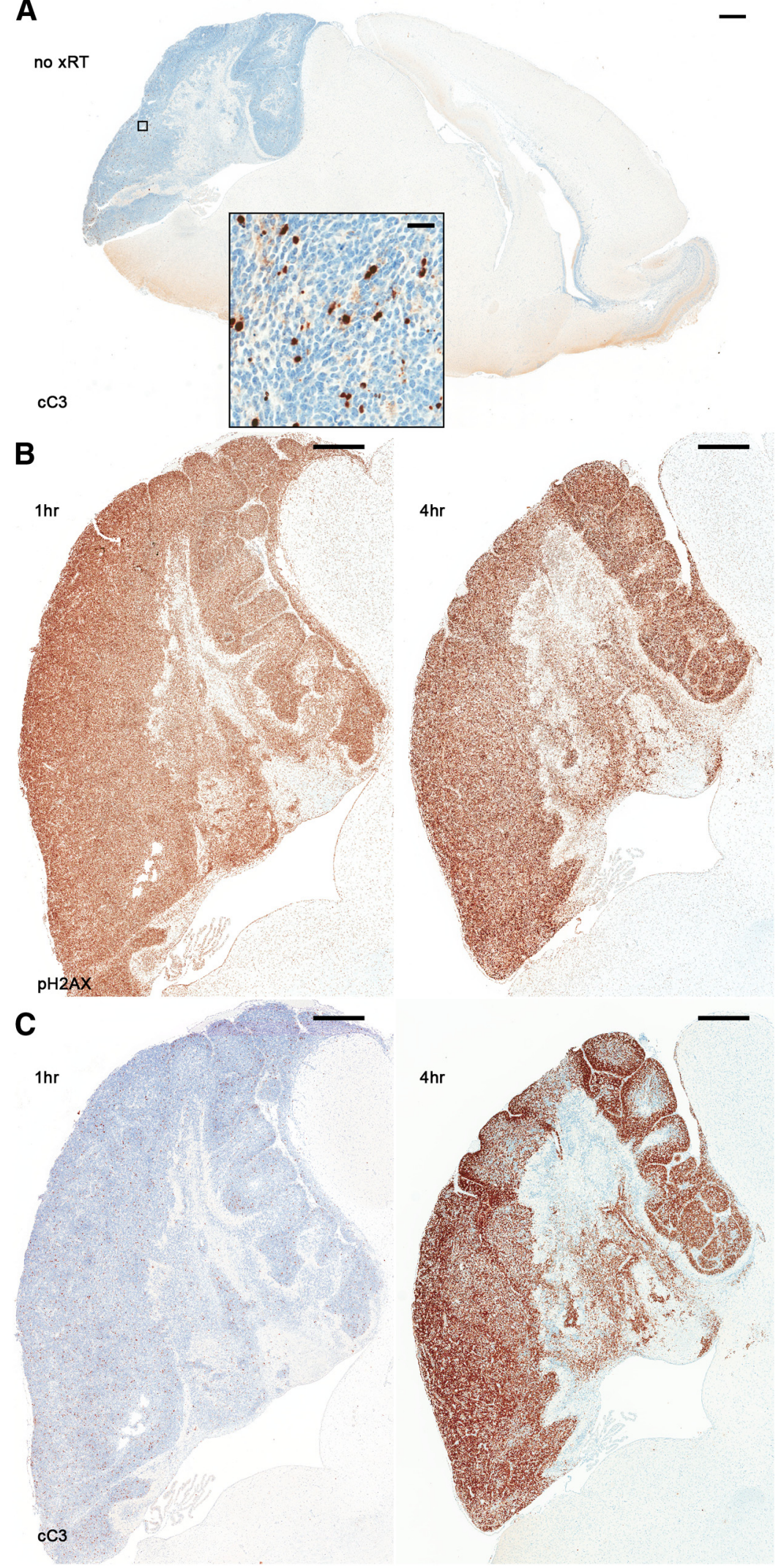

Figure 2. Medulloblastoma, like CGNPs, undergoes rapid apoptosis after genotoxic injury. $A$, IHC for CC3 demonstrates basal level of apoptosis typical of medulloblastoma in Math1-cre;SmoM2 mice. $B, 10 \mathrm{~Gy}$ xRT caused DNA damage throughout the tumor and adjacent cerebellum, which was detectable by IHC for pH2AX at 1 and $4 \mathrm{~h}$ after treatment. C, As in CGNPs, apoptosis was undetectable during the latent period after XRT ( $1 \mathrm{~h}$ ), then began precipitously in the tumor cells by $4 \mathrm{~h}$. Scale bars: $A-C, 500 \mu \mathrm{m}$; $A$ (inset), $50 \mu \mathrm{m}$.
Bax is the principal effector of CGNP death, and that Bak does not effectively compensate for Bax in these cells.

\section{Mitogenic signaling maintains active} Bax at mitochondria without apoptosis To understand how Bax drives the rapid, rigorously maintained pattern of CGNP death $4 \mathrm{~h}$ after proapoptotic stimulus, we examined the temporal sequence of Bax activation. We used IP with antibody 6A7 to detect $\mathrm{Bax}$ in the active conformation in lysates of whole cerebella or of isolated CGNPs, cultured in the presence or absence of Shh. Shh is the endogenous mitogen for CGNPs, and serum-free media supplemented with Shh maintains freshly isolated CGNPs in a proliferative state; cultured without Shh, CGNPs survive but stop dividing and differentiate (Wechsler-Reya and Scott, 1999; Kenney and Rowitch, 2000).

We were surprised to find that in the absence of proapoptotic stimulus, CGNPs maintain Bax in an active conformation. Importantly, activated Bax was markedly reduced when CGNPs differentiated to CGNs. Using immunoprecipitation, we detected active Bax in lysates of whole cerebella specifically during the period of CGNP proliferation (Fig. 4A). Smoothened-induced medulloblastomas, in both ND2:SmoA1 (Hallahan et al., 2004) and Math1-cre; SmoM2 mice, similarly demonstrated active Bax. Importantly, by isolating CGNPs, and adding or withholding Shh from cultures, we were able to determine that CGNPs maintain Bax in active conformation only when stimulated to proliferate (Fig. $4 B$ ). Subcellular fractionation of cultured CGNPs, moreover, demonstrated increased mitochondrial localization of $\mathrm{Bax}$ by CGNPs maintained in Shh (Fig. 4C). The conformational change and mitochondrial localization of Bax were not accompanied by increased apoptosis (Fig. 4D).

While the presence of active Bax in CGNPs did not cause spontaneous apoptosis, we noted that Shh-treated CGNPs were differentially sensitive to genotoxic stimulus. We pooled freshly harvested CGNPs, divided them into Shh- or vehiclesupplemented wells and subjected all wells to $10 \mathrm{~Gy}$ radiation, then harvested cultures for Western blot at progressively greater intervals. Shh-treated CGNPs initiated apoptosis by $3 \mathrm{~h}$ after irradiation, while vehicletreated CGNPs demonstrated minimal increase in cell death (Fig. 4E). Thus, proliferating CGNPs harbored active Bax, and while not committed to apoptosis, were primed to initiate rapid cell death after DNA damage. 


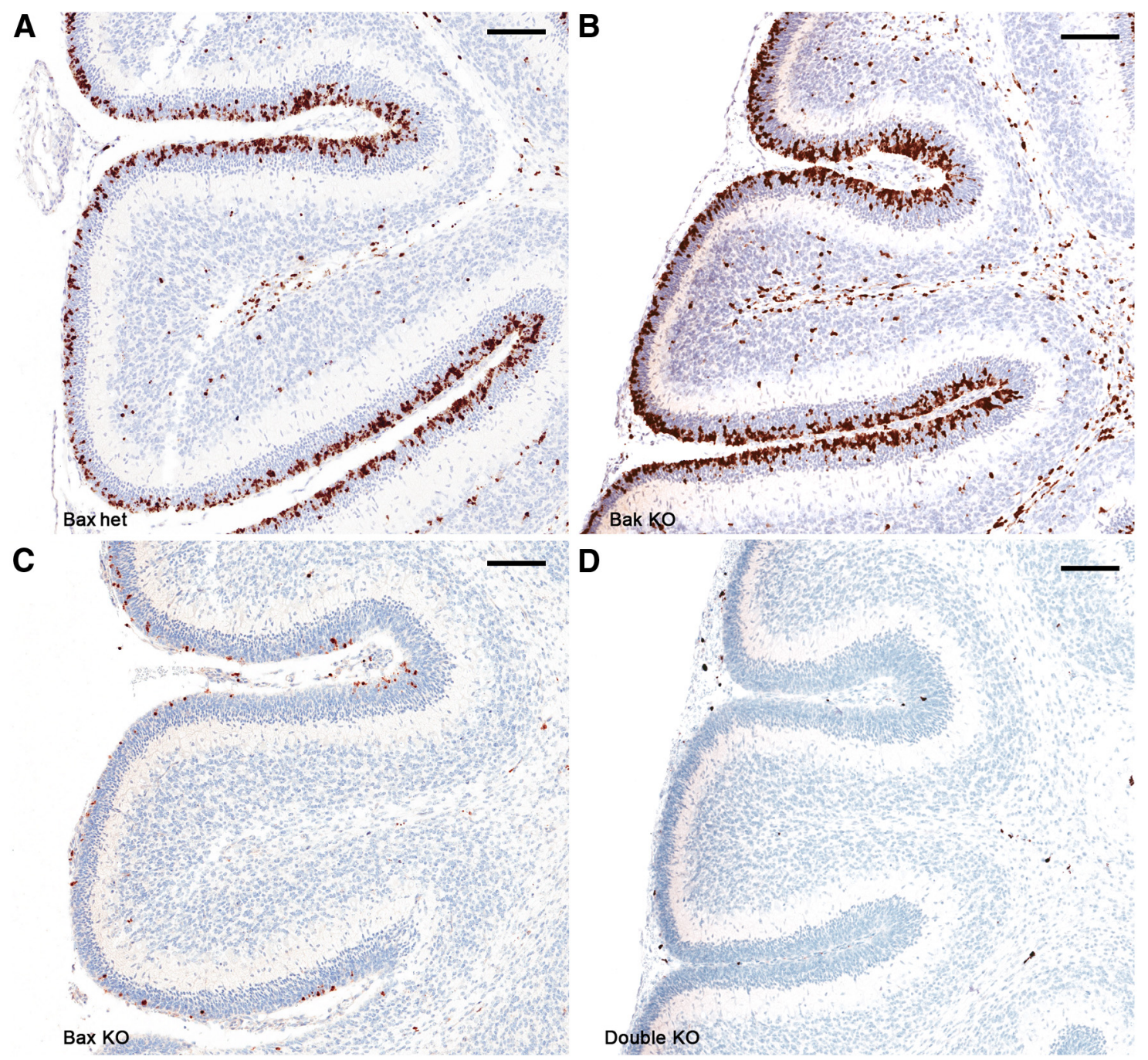

Figure 3. Vulnerability of CGNPs to apoptosis is not a direct consequence of cell cycling but rather depends specifically on Bax. A, Proliferating CGNPs in a Bax heterozygous mouse underwent precipitous apoptosis $4 \mathrm{~h}$ after XRT, as expected. B, Genetic deletion of Bak did not markedly alter the pattern of xRT-induced apoptosis. C, In contrast, genetic deletion of Bax dramatically reduced xRT-induced apoptosis, despite the presence of intact Bak. D, Conditional deletion of Bax in CGNPs, combined with genetic deletion of Bak, completely blocked the apoptotic effect of xRT. Scale bars, $100 \mu \mathrm{m}$.

\section{Preactivated Bax in CGNPs is sufficient to cause apoptosis}

To test whether the abundance of active Bax in CGNPs was sufficient to cause cell death, we examined the dynamics of Bax conformation changes elicited by proapoptotic stimulus. We induced CGNP apoptosis in vivo with systemic dexamethasone, and we analyzed the abundance of Bax detectable by 6A7 IP before or after treatment. While dexamethasone induced apoptosis in CGNPs $4 \mathrm{~h}$ after an IP dose as expected (Fig. $4 F$, input lysates), we detected equivalent active Bax in dexamethasone-injected and sham-injected mice (Fig. 4F, 6A7 IP). These data show that CGNPs harbor potentially lethal levels of active Bax, and can trigger cell death without additional Bax conformation change.

\section{Activation of Bax in CGNPs is increased by p53 and decreased by $\mathbf{p 4 4 / 4 2}$ MAPK}

Because of the correlation between proliferation and Bax activation we investigated the role of replication stress and canonical mitogenic signaling in controlling Bax conformation in CGNPs. Previous investigations have documented that disruption of DNA repair in CGNPs causes p53-dependent cell death (Orii et al., 2006), suggesting an endogenous tendency to suffer DNA damage during replication. We therefore tested whether $\mathrm{p} 53$ regulated the proportion of Bax that was activated in CGNPs. We found that active Bax was detectable, but markedly less abundant, in cerebellum lysates from pups with genetic deletion of p53 $\left(\mathrm{p} 53^{-/-}\right.$) compared with cerebellum lysates from $\mathrm{p} 53^{+/+}$littermates (Fig. 5A). Importantly, we found that Shh-maintained CGNPs increased expression of the BH3-only protein Puma (Fig. $5 B$ ), a mechanism previously noted to coordinate the activation of p53 and Bax in vitro (Chipuk et al., 2005). Thus, although p53 was not strictly required for tonic Bax activation, the proportion of active Bax was augmented through a p53-dependent mechanism, potentially mediated by Puma, that did not require exogenous proapoptotic stimulation.

While $\mathrm{p} 53$ positively regulated Bax activation, we found that the mitogen-activated protein kinase (MAPK) signaling activity correlated inversely with activation of Bax. To investigate the role of MAPK signaling in regulating Bax, we exposed Shh-treated CGNPs in vitro to the Mek inhibitor U0126. Mek activates Erk1 and Erk2 (p44/p42 MAPK) through phosphorylation. We found that U0126 markedly reduced phosphorylated p44 and p42 in CGNPs (Fig. 5C). Blocking Mek-Erk signaling did not inhibit 
A

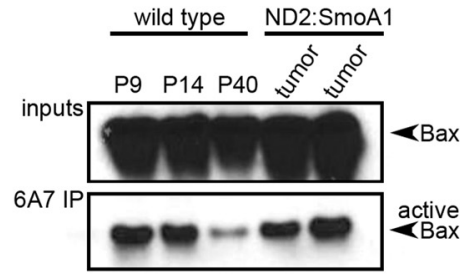

D

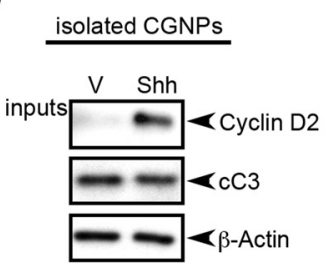

E$$
\text { E }
$$

B
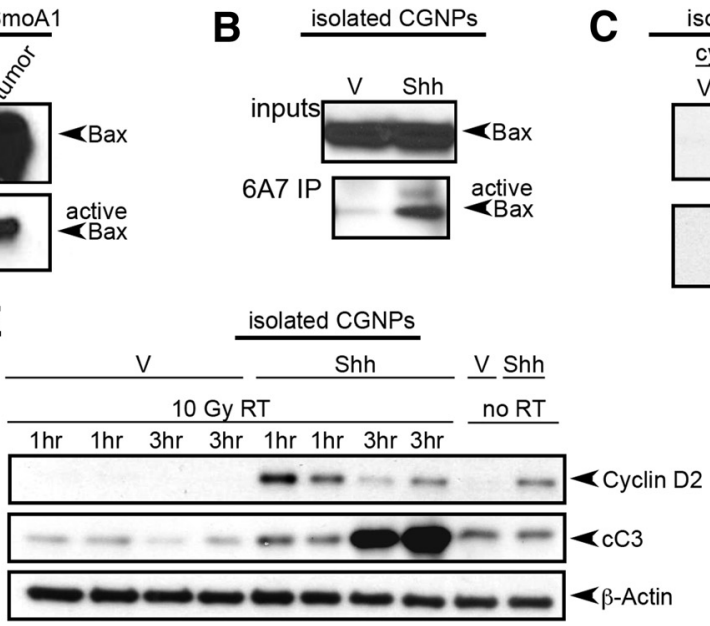

C isolated CGNPs - fractionated

cytosolic mitochondrial

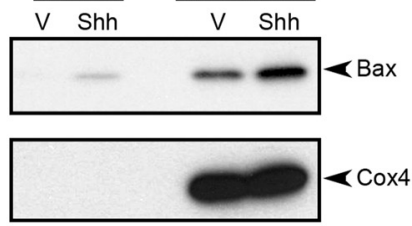

F

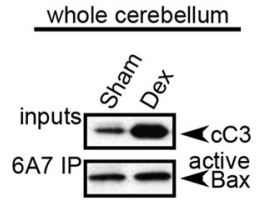

Figure 4. Proliferating CGNPs harbor active Bax in lethal abundance, enabling rapid commitment to cell death. $A$, Representative IP using Bax $6 \mathrm{~A} 7$ antibody on lysates of whole cerebellum or Smo-induced medulloblastoma demonstrate tonic activation of Bax during cerebellar neurogenesis and tumor growth. $B$, Isolated CGNPs harbor Bax in an active conformation only when maintained in Shh-containing media. C, Western blot for Bax after subcellular fractionation demonstrates increased Bax at mitochondria of CGNPs cultured in Shh, compared with CGNPs deprived of Shh (V). Western blot for Cox4 demonstrates effectiveness of mitochondrial enrichment. D. Western blots on the input lysates used in $\boldsymbol{B}$ : despite increased Bax activation, Shh-treated CGNPs did not demonstrate increased cC3. Increased Cyclin D2 in Shh-treated CGNPs confirms that Shh effectively maintained a proliferative state in vitro. $\boldsymbol{E}$, Isolated CGNPs maintained in Shh underwent radiation-induced apoptosis after a consistent latent period. CGNPs maintained in vehicle without Shh (V) did not undergo apoptosis after xRT. F, Dex induced apoptosis in CGNPs that was detectable by Western blot for cC3 in whole cerebellum lysates $4 \mathrm{~h}$ after intraperitoneal injection, without causing an increase in active Bax, as detected by $6 \mathrm{A7}$ IP.

A

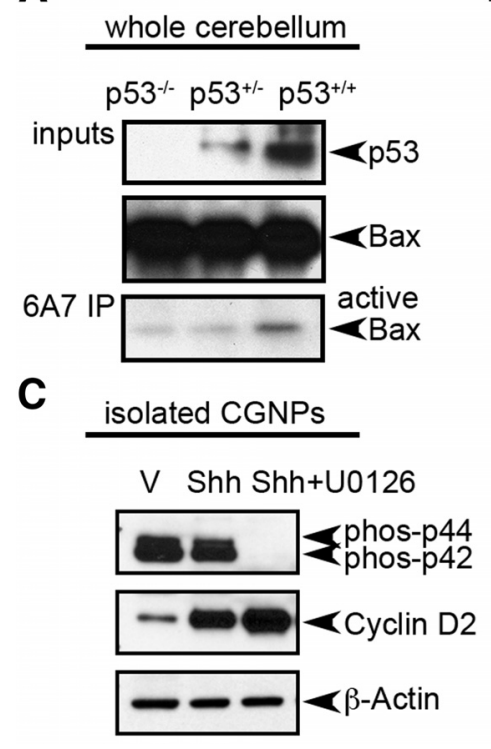

B isolated CGNPS

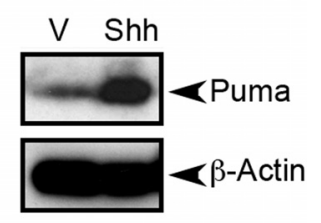

isolated CGNPs

V Shh Shh+U0126

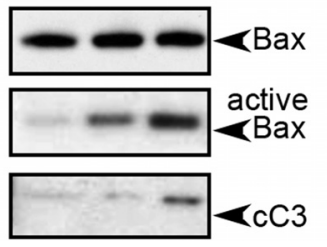

Figure 5. Bax activation is positively regulated by $p 53$ and negatively regulated by $\mathrm{p} 44 / \mathrm{p} 42$ MAPK. $A$, Genetic deletion of one or both copies of $\mathrm{p} 53$ caused a dose-dependent reduction in the proportion of active $B a x$, along with a reduction in the abundance of $p 53$ protein. Even in the absence of $p 53$, however, active Bax remained detectable by 6 A7 IP. B, Western blot demonstrates increased Puma in isolated G GNPs maintained in Shh. C, Western blot from CGNPs maintained in vitro demonstrates effective inhibition of p44/p42 MAPK phosphorylation by Mek inhibitor U0126. Mek inhibition did not block Shh-induced proliferation, as demonstrated by CGNP proliferation marker Cyclin D2. Mek inhibition produced an additive increase in Bax activation, demonstrated by 6A7 IP (middle panel of right column) that exceeded the effect of Shh alone.

CGNP proliferation, as demonstrated by persistent, slightly increased expression of CGNP proliferation marker Cyclin D2. When replicate wells were subjected to $6 \mathrm{~A} 7 \mathrm{IP}$, we found that compared with vehicle, Shh increased the proportion of Bax in active conformation, and this proportion was further increased by U0126 (Fig. 5C). Apoptosis followed the pattern of Bax acti-

vation as cC3 increased with U0126 treatment (Fig. 5C). Thus, p44/p42 MAPK inhibition in Shh-treated CGNPs produced an additive effect on Bax activation, indicating that p44/p42 MAPK negatively regulates Bax activation in CGNPs.

\section{Active Bax in CGNPs is bound to Bcl-xL}

The presence of active Bax in viable CGNPs implies a mechanism to prevent initiation of apoptosis. The antiapoptotic Bcl2 family protein $\mathrm{Bcl}-\mathrm{xL}$ has been previously demonstrated to bind to active Bax, allowing mitochondrial translocation without MOMP (Llambi et al., 2011). We examined the possibility that active Bax was present at mitochondria and bound to $\mathrm{Bcl}-\mathrm{xL}$ or its homologs Bcl-2 and Mcl-1, by comparing lysates of whole cerebella either during peak CGNP proliferation (P7) or after CGNPs had completed differentiation (adult). We subjected lysates from P7 or adult cerebella to IP with Bax antibody 6A7, then detected Bcl-2, Bcl-xL, and Mcl-1 by Western blot. While all three antiapoptotic proteins were detectable in cerebellum lysates (Fig. $6 \mathrm{~A}$, inputs lanes), only Bcl-xL coprecipitated with active Bax, and only at P7 (Fig. 6A, 6A7 IP lanes). Thus, active Bax interacted specifically with Bcl-xL, specifically during the period of CGNP proliferation. Consistent with these data, IP for Bcl-xL followed by Western blot for Bax confirmed the Bax:Bcl-xL interaction during postnatal cerebellar neurogenesis (Fig. 6B). Together, these findings demonstrate that active Bax associates specifically with Bcl-xL in proliferating CGNPs.

To exclude the possibility that $\mathrm{Bcl} 2$ homologs other than $\mathrm{Bcl}-\mathrm{xL}$ regulate Bax in CGNPs, we examined whether deleting Mcl-1 in these cells causes apoptosis. Previous investigations have shown that in contrast to $\mathrm{Bcl}-2$, which is not required during brain development (Veis et al., 1993; Nakayama et al., 1994; Kamada et al., 1995), Mcl-1 is required for the survival of primitive neuro-glial stem cells that are targeted by Nestin-cre (Arbour et al., 2008). Our finding that Mcl-1 did not immunoprecipitate with active Bax in CGNPs, however, suggested that Mcl-1 might not regulate the survival of these less pluripotent, neural progenitors. We assayed the dependence of CGNPs on Mcl-1 by testing the effect of conditional Mcl-1 deletion. We bred Mcl-1 floxed 
A

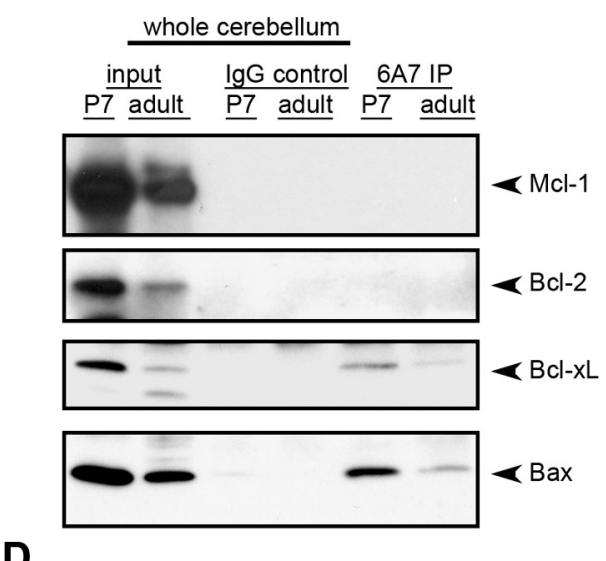

B

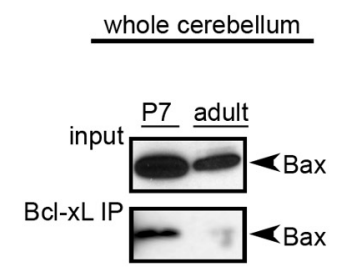

C

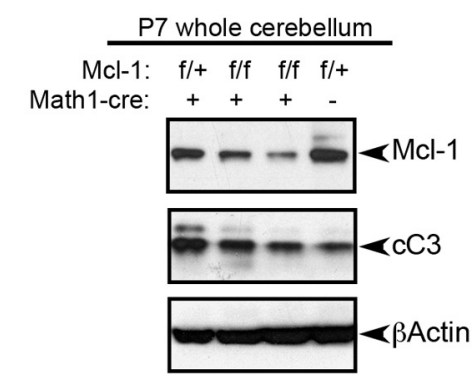

E

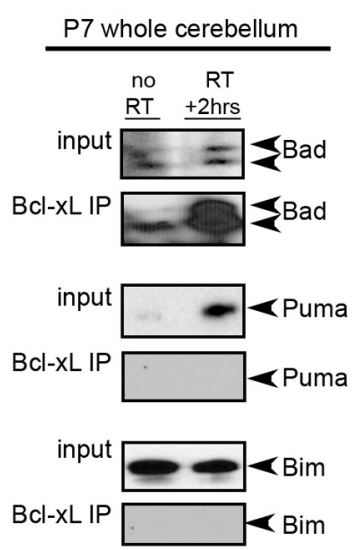

$\mathbf{F}$ isolated CGNPs - fractionated cytosolic mitochondrial no RT no RT $\underline{\mathrm{RT}}+2$ hrs $\underline{\mathrm{RT}}+2$ hrs

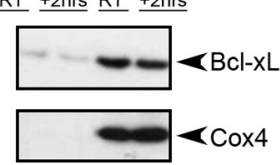

Figure 6. BCl-xL interacts with active Bax in nonapoptotic CGNPs, and with Bad after induction of apoptosis, while genetic deletion excludes Mcl-1 as a key modulator of CGNP survival. $A$, Representative Western blots for MCl-1, BCl2, BCl-xL, and Bax using lysates of whole cerebellum from P7 or adult mice, before and after IP with Bax $6 \mathrm{A7}$ antibody. Of the antiapoptotic BCI2 family protein tested, only BCl-xL interacted with active Bax during cerebellar neurogenesis. $B$, Representative Western blot for Bax, reciprocal to $A$, before and after IP using BCl-xL antibodies, confirms the temporal pattern of Bax:BCl-xL interaction. C, Western blot demonstrates reduced Mcl-1 protein in whole cerebellum lysates of Math1-cre;Mcl-1 ${ }^{\mathrm{f} / \mathrm{f}}$ mice compared with littermate controls, with no detectable increase in CC3. D, Representative sections of cerebellum from littermates with indicated genotype, stained with H\&E (top) or by IHC for CC3 (bottom). Boxes in top panels demonstrate the regions magnified in the bottom, where the EGL is identified. No increase in apoptosis was found in (GNPs with Mcl-1 deletion. Scale bars: $200 \mu \mathrm{m}$ (top); $50 \mu \mathrm{m}$ (bottom). $\boldsymbol{E}$, Representative Western blots for Bad, PUMA, and BIM, before and after IP with BCl-xL antibody. Whole cerebella from P7 mice are compared, either with no proapoptotic stimulus or $2 \mathrm{~h}$ after $10 \mathrm{~Gy}$ of radiation. XRT induced binding of BCl-xL to Bad during this latent period before radiation-induced apoptosis begins. $F$, Western blot for BCl-xL or mitochondrial marker Cox4 after subcellular fractionation. Two hours after xRT, no redistribution of Bcl-xL from mitochondria to cytoplasm was observed.

mice (Dzhagalov et al., 2007) with Math1-cre mice, to delete Mcl-1 in committed neural progenitors including the CGNP population (Machold and Fishell, 2005; Wang et al., 2005). Western blot analysis of whole cerebellum at P7 demonstrated decreased Mcl-1 protein, but no significant increase in cleavage of caspase-3 (Fig. 6C). Histologic analysis demonstrated no defects in the layers of CGNPs that form the EGL and no increase in cC3 + CGNPs (Fig. 6D). Thus, disrupting Mcl-1 in CGNPs was not sufficient to induce cell death. Together, our data support a model in which CGNPs and medulloblastoma cells modulate commitment to cell death by maintaining Bax in an active state, and by strictly modulating the tendency of active Bax to trigger apoptosis via interaction specifically with antiapoptotic Bcl-xL.

Bad, Puma, and Bim are BH3-only proteins that have been reported to antagonize the antiapoptotic effect of $\mathrm{Bcl}-\mathrm{xL}$ in diverse cells (Yang et al., 1995; Willis et al., 2005; Chipuk and
Green, 2009; Follis et al., 2013; Kodama et al., 2013). To identify proteins that act on $\mathrm{Bcl}-\mathrm{xL}$ at the initiation of apoptosis in CGNPs, we compared the expression of Bad, Puma, and Bim, and the interaction of these proteins with Bcl-xL, before and shortly after apoptotic stimulation. We harvested whole cerebella at P7, during the peak of CGNP proliferation, and compared them to P7 cerebella of mice that were exposed to 10Gy xRT focused on the posterior fossa. Radiated mice were harvested $2 \mathrm{~h}$ after treatment to obtain CGNPs after proapoptotic stimulus but before caspase- 3 cleavage and DNA fragmentation. Harvested cerebella were lysed and analyzed by Western blot to compare untreated samples to radiated samples. We found that Bad and Puma both increased in abundance with xRT. Only Bad, however, coprecipitated with Bcl-xL, and this interaction increased markedly with xRT (Fig. 6E). In contrast to this increase in Bcl-xL:Bad interaction with initiation of cell death, we did not find a change in 
A

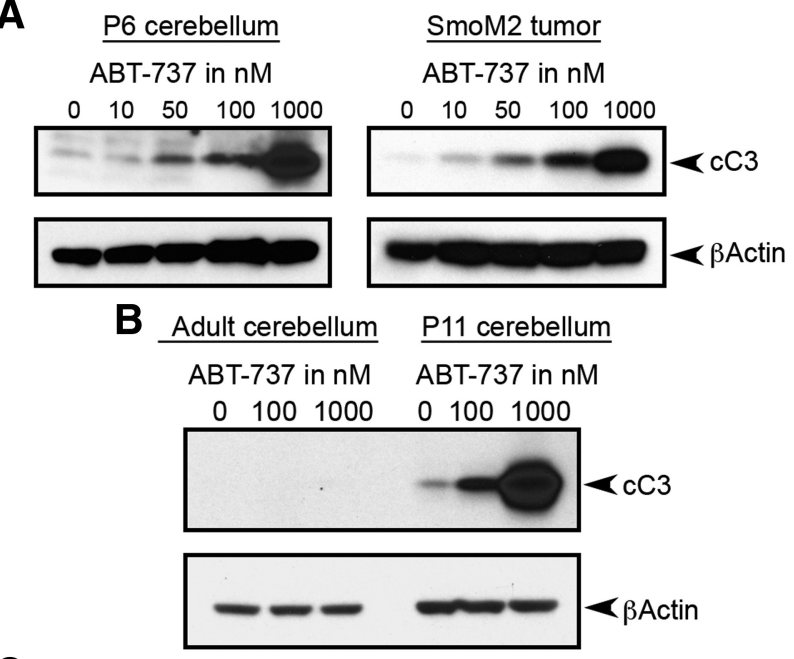

C
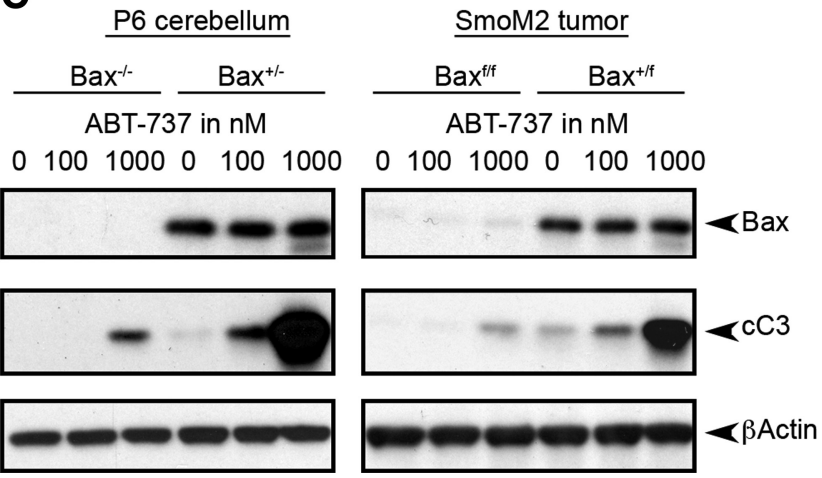

Figure 7. BH3-mimetic agent ABT 737 induces rapid, Bax-dependent apoptosis of proliferating CGNPs and medulloblastoma cells. $A$, ABT 737 induced highly rapid apoptosis of dissociated cerebellar progenitors and medulloblastoma cells $1 \mathrm{~h}$ after exposure, in a dose-dependent manner, as demonstrated by Western blot for CC 3 . B Adult cerebellum, which contains all cerebellar cell types except CGNPs, did not demonstrate apoptosis after $1 \mathrm{~h}$ of exposure to ABT 737. P11 cerebellum, which contains CGNPs, demonstrated robust, dose-dependent apoptosis. C, The induction of apoptosis in CGNPs and medulloblastoma cells by ABT 737 was markedly reduced by genetic deletion of Bax.

$\mathrm{Bcl}-\mathrm{xL}$ localization. We performed subcellular fractionation on isolated CGNPs, either without radiation or $2 \mathrm{~h}$ after 10Gy xRT. We than analyzed cytosolic and mitochondrial fractions by Western blot for Bcl-xL and Cox4. We found Bcl-xL, like Cox4, predominantly in the mitochondrial fraction both before and after xRT (Fig. $6 F$ ). Thus, Bcl-xL did not translocate out of mitochondria with provocation of apoptosis. These data suggest that CGNP apoptosis is triggered at the mitochondria, where increased Bcl-xL:Bad interaction releases activated Bax.

\section{BH3-mimetic agent ABT 737 rapidly induces Bax-driven apoptosis in CGNPs and medulloblastoma in the absence of genotoxic injury}

To determine the functional significance of the interaction between active $\mathrm{Bax}$ and $\mathrm{Bcl}-\mathrm{xL}$ in CGNPs, we used the $\mathrm{BH} 3$ mimetic agent ABT 737 to disrupt Bax:Bcl-xL binding (Oltersdorf et al., 2005; Kang and Reynolds, 2009; Vogler et al., 2009). Because ABT37 does not penetrate the blood-brain barrier, we developed the technique of exposing freshly harvested, dissociated cerebellum or tumor to ABT 737 in vitro, then measuring apoptosis by Western blot for $\mathrm{CC} 3$. Remarkably, after only $1 \mathrm{~h}$ of exposure to ABT 737, both CGNPs and medulloblastoma cells underwent apoptosis precipitously, in a dose-dependent manner (Fig. 7A).
This unexpectedly rapid induction of cell death contrasted with the induction of cell death after xRT or corticosteroid exposure, which consistently followed a latent period. Sensitivity to ABT 737 depended on the differentiation state of CGNPs, as ABT 737 did not induce death in dissociated cells from adult cerebella (Fig. $7 B)$. Importantly, the proapoptotic effect of ABT 737 was abrogated in CGNPs and medulloblastomas from Bax-deficient mice (Fig. $7 C$ ). Thus, the rapid induction of death triggered in these cells by ABT 737 was specifically Bax dependent and developmentally regulated.

\section{Discussion}

In this investigation we have demonstrated that primary neural progenitors, like embryonic stem cells, are configured for rapid, Bax-dependent cell death. While a variety of stimuli were able to initiate CGNP apoptosis, the timing of death remained constant, beginning synchronously after a consistent latent period of $>1 \mathrm{~h}$ and $<4 \mathrm{~h}$. The capacity for CGNPs to undergo cell death was tied to their proliferation state: differentiating CGNPs of the inner EGL did not initiate apoptosis after xRT, and Shh-deprived CGNPs in culture were similarly radiation resistant. Importantly, we found that the developmental mitogen Shh maintained not only the proliferation of CGNPs but also the presence of active Bax within these cells. Like proliferating CGNPs, cells of primary mouse medulloblastoma harbored active Bax and were prone to synchronous apoptosis at a defined interval after xRT. Moreover, we found that survival of CGNPs and medulloblastoma cells required the interaction of active Bax with Bcl-xL. Thus, CGNPs are configured for rapid cell death by the presence of preactivated Bax, held in check at mitochondria, and this mechanism remains engaged after malignant transformation to medulloblastoma.

Like human ES cells, CGNPs maintain a capacity for rapid initiation of apoptosis by harboring active Bax. However, CGNPs responded to ABT 737 with extremely rapid induction of apoptosis, while we previously found that ABT 737 did not induce death in human ES cells (Dumitru et al., 2012). This differential sensitivity highlights key differences in the regulation of Bax in ES cells and CGNPs. While ES cells sequester Bax in the Golgi, CGNPs maintain active Bax at mitochondria where it triggers MOMP when released from the inhibitory effect of Bcl-xL. This mechanism renders CGNPs acutely dependent on the antiapoptotic effect of Bcl-xL and thus rapidly vulnerable to ABT 737. Importantly, our finding that DNA damage induced the $\mathrm{BH} 3$-only protein $\mathrm{Bad}$ to bind $\mathrm{Bcl}-\mathrm{xL}$ suggests that $\mathrm{Bad}$ is the endogenous trigger for MOMP that is bypassed by ABT 737. Thus, although tonic activation of Bax is a common feature of ES cells and CGNPs, each cell type has a specific mechanism of maintaining its closely regulated survival.

The ability of CGNPs to survive deletion of Mcl-1 further demonstrates that survival mechanisms are cell-type specific even within the limited subset of brain precursors. In previous investigations, conditional deletion of Mcl-1 with FoxG1-cre or Nestin-cre caused embryonic lethality, with widespread apoptosis in the telencephalon at E12.5, and thus demonstrated that survival of early telencephalic neuro-glial precursors requires Mcl-1 (Arbour et al., 2008). In contrast, we found that mice in which Mcl-1 was conditionally deleted in unipotent neural progenitors with Math1-cre were viable and without overt neurologic deficits. Mcl-1-deficient CGNPs did not demonstrate increased apoptosis and generated a normal appearing EGL. Thus, although CGNPs were so dependent on antiapoptotic proteins that ABT 737 provoked Bax-dependent death within $1 \mathrm{~h}$, these cells survived Mcl-1 deletion. Our findings demonstrate 
that the vulnerability of postnatal neural progenitors is not a consequence of their rapid proliferation, but rather the outcome of a highly specific molecular process of survival regulation.

The mechanism of Bax activation in CGNPs remains to be elucidated. Previous investigations have demonstrated that Bax can be activated either by $\mathrm{BH} 3$-only proteins, including Puma (Letai et al., 2002; Melino et al., 2004; Kuwana et al., 2005) or directly by p53 (Chipuk et al., 2004). Our finding that Bax activation was positively regulated by $\mathrm{p} 53$ is consistent with both possibilities. Puma was initially identified as a $\mathrm{BH} 3$-only protein upregulated by p53 (Nakano and Vousden, 2001). We found that Puma was upregulated by DNA damage induced by xRT and also by Shh. It is possible that Shh-induced proliferation causes endogenous genotoxic injury through replication stress, and that this stress induces p53-mediated upregulation of Puma. Thus, Puma may link proliferation to activation of Bax. Nevertheless, additional activators of Bax must function in CGNPs as p53 deletion reduced Bax activation in CGNPs but did not eliminate it. The presence of redundant systems of Bax activation would also be consistent with the observation that p53 deletion does not prevent corticosteroid-induced CGNP apoptosis (Noguchi et al., 2008).

Conversely, we found that $\mathrm{p} 44 / \mathrm{p} 42$ MAPK signaling negatively regulated Bax activation in proliferating Shh-treated CGNPs. Inhibiting this pathway through Mek inhibition increased the proportion of activated Bax and promoted apoptosis. Importantly, the link between proliferation and Bax activation was not altered by Mek inhibition, as Shh-induced proliferation did not decrease. Our data are consistent with previous studies that demonstrated that p44/p42 MAPK is not required for Shhinduced proliferation (Kenney and Rowitch, 2000). Our data are also consistent with previous studies that demonstrated an antiapoptotic effect of p44/p42 MAPK in cerebellar granule neurons differentiated from CGNPs in vitro by Shh withdrawal (Bonni et al., 1999). Together, these findings demonstrate a role for $\mathrm{p} 44 /$ p42 MAPK signaling in maintaining the survival of both CGNPs and their differentiated progeny.

Previous investigators have delineated models of apoptosis regulation in which viable cells maintain Bax and Bak alternately in an inactive conformation, or in a constitutively active conformation but suppressed by antiapoptotic proteins (Letai et al., 2002; Green, 2006). The latter model in which antiapoptotic proteins are required to prevent active Bax from inducing MOMP has been described as addiction to antiapoptotic proteins that leaves cells "primed for death." The primed-for-death state has previously been attributed to growth factor withdrawal, physiologic stress, or malignant growth (Certo et al., 2006). Importantly, in CGNPs we have identified a cell type that is primed for death in the course of unperturbed development in vivo. In these progenitors, the addiction to antiapoptotic proteins, demonstrated by ABT 737 sensitivity, is not a consequence of exogenous stress but rather a developmentally regulated phenotype. This developmental primed-for-death state seems well suited to the specific context of postnatal neurogenesis, in which individual cells are replaceable and preventing the propagation of mutations is paramount. In this context, the remarkable sensitivity of medulloblastoma to cytotoxic therapy may be understood as inherited from the premalignant cells of origin.

Importantly, the sensitivity of neural progenitors to DNAdamaging therapies has emerged as a clinically significant problem that may contribute to the lingering encephalopathy after cancer treatment, commonly referred to as "chemobrain" (Christie et al., 2012; Monje and Dietrich, 2012). While we inves- tigated Bax regulation in CGNPs, neural progenitors of the hippocampus and subventricular zone may be similarly calibrated to undergo rapid cell death through tonic Bax activation. The therapy that effectively treats medulloblastoma also causes long-term cognitive decline (Ris et al., 2013). Our data suggest a common mechanism links the sensitivity of brain progenitors and medulloblastoma.

We found that medulloblastoma maintained the tonic activation of Bax that was typical of proliferating CGNPs. A malignant tumor of neural progenitors, medulloblastoma has long been known to be markedly more sensitive to cytotoxic therapy than other malignant brain tumors. We have previously found that spontaneous apoptosis is an active process active in both mouse medulloblastoma and in medulloblastomas resected from patients. The possibility that tumor cells in human medulloblastoma are primed for death is supported by the manifest sensitivity of medulloblastoma to DNA-damaging therapy (Packer et al., 2006; Packer and Vezina, 2008) and by our previous observation that the rate of apoptosis varies inversely with the expression of antiapoptotic Bcl-2 (Garcia et al., 2013). Our current findings that CGNPs and medulloblastoma cells maintain Bax in active conformation suggests a potential mechanism for the known sensitivity of medulloblastoma to therapies that act through DNA damage and relate this sensitivity to the developmental cell of origin. The strong vulnerability of medulloblastoma to the Bcl2/Bcl-xL inhibitor ABT 737 in our model, moreover, suggests that targeting specific antiapoptotic Bcl-2 family proteins may be a new avenue for medulloblastoma therapy.

\section{References}

Antonsson B, Montessuit S, Sanchez B, Martinou JC (2001) Bax is present as a high molecular weight oligomer/complex in the mitochondrial membrane of apoptotic cells. J Biol Chem 276:11615-11623. CrossRef Medline Arbour N, Vanderluit JL, Le Grand JN, Jahani-Asl A, Ruzhynsky VA, Cheung EC, Kelly MA, MacKenzie AE, Park DS, Opferman JT, Slack RS (2008) Mcl-1 is a key regulator of apoptosis during CNS development and after DNA damage. J Neurosci 28:6068-6078. CrossRef Medline

Ayrault O, Zindy F, Rehg J, Sherr CJ, Roussel MF (2009) Two tumor suppressors, p27Kip1 and patched-1, collaborate to prevent medulloblastoma. Mol Cancer Res 7:33-40. Medline

Bhatia B, Malik A, Fernandez-L A, Kenney AM (2010) p27(Kip1), a doubleedged sword in Shh-mediated medulloblastoma: Tumor accelerator and suppressor. Cell Cycle 9:4307-4314. CrossRef Medline

Bonni A, Brunet A, West AE, Datta SR, Takasu MA, Greenberg ME (1999) Cell survival promoted by the Ras-MAPK signaling pathway by transcription-dependent and -independent mechanisms. Science 286: 1358-1362. CrossRef Medline

Certo M, Del Gaizo Moore V, Nishino M, Wei G, Korsmeyer S, Armstrong SA, Letai A (2006) Mitochondria primed by death signals determine cellular addiction to antiapoptotic BCL-2 family members. Cancer Cell 9:351-365. CrossRef Medline

Chipuk JE, Green DR (2009) PUMA cooperates with direct activator proteins to promote mitochondrial outer membrane permeabilization and apoptosis. Cell Cycle 8:2692-2696. CrossRef Medline

Chipuk JE, Kuwana T, Bouchier-Hayes L, Droin NM, Newmeyer DD, Schuler M, Green DR (2004) Direct activation of Bax by p53 mediates mitochondrial membrane permeabilization and apoptosis. Science 303:1010 1014. CrossRef Medline

Chipuk JE, Bouchier-Hayes L, Kuwana T, Newmeyer DD, Green DR (2005) PUMA couples the nuclear and cytoplasmic proapoptotic function of p53. Science 309:1732-1735. CrossRef Medline

Chong MJ, Murray MR, Gosink EC, Russell HRC, Srinivasan A, Kapsetaki M, Korsmeyer SJ, McKinnon PJ (2000) Atm and Bax cooperate in ionizing radiation-induced apoptosis in the central nervous system. Proc Nat Acad Sci U S A 97:889-894. CrossRef Medline

Christie LA, Acharya MM, Parihar VK, Nguyen A, Martirosian V, Limoli CL (2012) Impaired cognitive function and hippocampal neurogenesis following cancer chemotherapy. Clin Cancer Res 18:1954-1965. Medline 
Dumitru R, Gama V, Fagan BM, Bower JJ, Swahari V, Pevny LH, Deshmukh M (2012) Human embryonic stem cells have constitutively active Bax at the Golgi and are primed to undergo rapid apoptosis. Mol Cell 46:573583. CrossRef Medline

Dzhagalov I, St John A, He YW (2007) The antiapoptotic protein Mcl-1 is essential for the survival of neutrophils but not macrophages. Blood 109: 1620-1626. CrossRef Medline

Follis AV, Chipuk JE, Fisher JC, Yun MK, Grace CR, Nourse A, Baran K, Ou L, Min L, White SW, Green DR, Kriwacki RW (2013) PUMA binding induces partial unfolding within BCL-xL to disrupt p53 binding and promote apoptosis. Nat Chem Biol 9:163-168. CrossRef Medline

Garcia I, Crowther AJ, Gama V, Ryan Miller C, Deshmukh M, Gershon TR (2013) Bax deficiency prolongs cerebellar neurogenesis, accelerates medulloblastoma formation and paradoxically increases both malignancy and differentiation. Oncogene 32:2304-2314. CrossRef Medline

Green DR (2006) At the gates of death. Cancer Cell 9:328-330. CrossRef Medline

Grimmer MR, Weiss WA (2006) Childhood tumors of the nervous system as disorders of normal development. Curr Opin Pediatr 18:634-638. CrossRef Medline

Hallahan AR, Pritchard JI, Hansen S, Benson M, Stoeck J, Hatton BA, Russell TL, Ellenbogen RG, Bernstein ID, Beachy PA, Olson JM (2004a) The SmoAl mouse model reveals that notch signaling is critical for the growth and survival of sonic hedgehog-induced medulloblastomas. Cancer Res 64:7794-7800. Medline

Heine VM, Rowitch DH (2009) Hedgehog signaling has a protective effect in glucocorticoid-induced mouse neonatal brain injury through an 11 $\beta$ HSD2-dependent mechanism. J Clin Invest 119:267-277. Medline

Hitzert MM, Benders MJNL, Roescher AM, van Bel F, de Vries LS, Bos AF (2012) Hydrocortisone vs. dexamethasone treatment for bronchopulmonary dysplasia and their effects on general movements in preterm infants. Pediatr Res 71:100-106. CrossRef Medline

Hsu YT, Youle RJ (1997) Nonionic detergents induce dimerization among members of the Bcl-2 family. J Biol Chem 272:13829-13834. CrossRef Medline

Hsu YT, Wolter KG, Youle RJ (1997) Cytosol-to-membrane redistribution of Bax and Bcl-X(L) during apoptosis. Proc Natl Acad Sci U S A 94:36683672. CrossRef Medline

Kamada S, Shimono A, Shinto Y, Tsujimura T, Takahashi T, Noda T, Kitamura Y, Kondoh H, Tsujimoto Y (1995) bcl-2 deficiency in mice leads to pleiotropic abnormalities: accelerated lymphoid cell death in thymus and spleen, polycystic kidney, hair hypopigmentation, and distorted small intestine. Cancer Res 55:354-359. Medline

Kang MH, Reynolds CP (2009) Bcl-2 inhibitors: targeting mitochondrial apoptotic pathways in cancer therapy. Clin Cancer Res 15:1126-1132. Medline

Kenney AM, Rowitch DH (2000) Sonic hedgehog promotes G1 cyclin expression and sustained cell cycle progression in mammalian neuronal precursors. Mol Cell Biol 20:9055-9067. CrossRef Medline

Kenney AM, Cole MD, Rowitch DH (2003) Nmyc upregulation by sonic hedgehog signaling promotes proliferation in developing cerebellar granule neuron precursors. Development 130:15-28. CrossRef Medline

Knudson CM, Tung KS, Tourtellotte WG, Brown GA, Korsmeyer SJ (1995) Bax-deficient mice with lymphoid hyperplasia and male germ cell death. Science 270:96-99. CrossRef Medline

Kodama T, Hikita H, Kawaguchi T, Saito Y, Tanaka S, Shigekawa M, Shimizu S, Li W, Miyagi T, Kanto T, Hiramatsu N, Tatsumi T, Takehara T (2013) The Bcl-2 homology 3 (BH3)-only proteins Bim and Bid are functionally active and restrained by anti-apoptotic B-cell CLL/lymphoma 2 (Bcl-2) family proteins in healthy liver. J Biol Chem 288:30009-30018. CrossRef Medline

Kuwana T, Bouchier-Hayes L, Chipuk JE, Bonzon C, Sullivan BA, Green DR, Newmeyer DD (2005) BH3 domains of BH3-only proteins differentially regulate Bax-mediated mitochondrial membrane permeabilization both directly and indirectly. Mol Cell 17:525-535. CrossRef Medline

Lee Y, Shull ER, Frappart PO, Katyal S, Enriquez-Rios V, Zhao J, Russell HR, Brown EJ, McKinnon PJ (2012) ATR maintains select progenitors during nervous system development. The EMBO J 31:1177-1189. CrossRef

Letai A, Bassik MC, Walensky LD, Sorcinelli MD, Weiler S, Korsmeyer SJ (2002) Distinct BH3 domains either sensitize or activate mitochondrial apoptosis, serving as prototype cancer therapeutics. Cancer Cell 2:183192. CrossRef Medline
Llambi F, Moldoveanu T, Tait SWG, Bouchier-Hayes L, Temirov J, McCormick LL, Dillon CP, Green DR (2011) A unified model of mammalian BCL-2 protein family interactions at the mitochondria. Mol Cell 44:517531. CrossRef Medline

Machold R, Fishell G (2005) Math1 is expressed in temporally discrete pools of cerebellar rhombic-lip neural progenitors. Neuron 48:17-24. CrossRef Medline

Mao J, Ligon KL, Rakhlin EY, Thayer SP, Bronson RT, Rowitch D, McMahon AP (2006) A novel somatic mouse model to survey tumorigenic potential applied to the hedgehog pathway. Cancer Res 66:10171-10178. Medline

Matei V, Pauley S, Kaing S, Rowitch D, Beisel KW, Morris K, Feng F, Jones K, Lee J, Fritzsch B (2005) Smaller inner ear sensory epithelia in Neurog1 null mice are related to earlier hair cell cycle exit. Dev Dyn 234:633-650. CrossRef Medline

Melino G, Bernassola F, Ranalli M, Yee K, Zong WX, Corazzari M, Knight RA, Green DR, Thompson C, Vousden KH (2004) p73 induces apoptosis via PUMA transactivation and Bax mitochondrial translocation. J Biol Chem 279:8076-8083. Medline

Miale IL, Sidman RL (1961) An autoradiographic analysis of histogenesis in the mouse cerebellum. Exp Neurol 4:277-296. CrossRef Medline

Miyazawa K, Himi T, Garcia V, Yamagishi H, Sato S, Ishizaki Y (2000) A Role for $\mathrm{p} 27 / \mathrm{Kip} 1$ in the control of cerebellar granule cell precursor proliferation. J Neurosci 20:5756-5763. Medline

Monje M, Dietrich J (2012) Cognitive side effects of cancer therapy demonstrate a functional role for adult neurogenesis. Behav Brain Res 227:376379. CrossRef Medline

Nakano K, Vousden KH (2001) PUMA, a novel proapoptotic gene, is induced by p53. Mol Cell 7:683-694. CrossRef Medline

Nakayama K, Negishi I, Kuida K, Sawa H, Loh DY (1994) Targeted disruption of Bcl-2 alpha beta in mice: occurrence of gray hair, polycystic kidney disease, and lymphocytopenia. Proc Natl Acad Sci U S A 91:3700-3704. CrossRef Medline

Noguchi KK, Walls KC, Wozniak DF, Olney JW, Roth KA, Farber NB (2008) Acute neonatal glucocorticoid exposure produces selective and rapid cerebellar neural progenitor cell apoptotic death. Cell Death Differ 15:15821592. CrossRef Medline

Oltersdorf T, Elmore SW, Shoemaker AR, Armstrong RC, Augeri DJ, Belli BA, Bruncko M, Deckwerth TL, Dinges J, Hajduk PJ, Joseph MK, Kitada S, Korsmeyer SJ, Kunzer AR, Letai A, Li C, Mitten MJ, Nettesheim DG, Ng S, Nimmer PM, et al. (2005) An inhibitor of Bcl-2 family proteins induces regression of solid tumours. Nature 435:677-681. CrossRef Medline

Orii KE, Lee Y, Kondo N, McKinnon PJ (2006) Selective utilization of nonhomologous end-joining and homologous recombination DNA repair pathways during nervous system development. Proc Natl Acad Sci U S A 103:10017-10022. CrossRef Medline

Packer RJ, Vezina G (2008) Management of and prognosis with medulloblastoma: therapy at a crossroads. Arch Neurol 65:1419-1424. CrossRef Medline

Packer RJ, Gajjar A, Vezina G, Rorke-Adams L, Burger PC, Robertson PL, Bayer L, LaFond D, Donahue BR, Marymont MH, Muraszko K, Langston J, Sposto R (2006) Phase III study of craniospinal radiation therapy followed by adjuvant chemotherapy for newly diagnosed average-risk medulloblastoma. J Clin Oncol 24:4202-4208. CrossRef Medline

Parathath SR, Mainwaring LA, Fernandez-L A, Guldal CG, Nahlé Z, Kenney AM (2010) beta-Arrestin-1 links mitogenic sonic hedgehog signaling to the cell cycle exit machinery in neural precursors. Cell Cycle 9:4013-4024. CrossRef Medline

Ris MD, Walsh K, Wallace D, Armstrong FD, Holmes E, Gajjar A, Zhou T, Packer RJ (2013) Intellectual and academic outcome following two chemotherapy regimens and radiotherapy for average-risk nedulloblastoma: COG A9961. Pediatr Blood Cancer 60:1350-1357. CrossRef Medline

Roussel MF, Hatten ME (2011) Cerebellum development and medulloblastoma. Curr Top Dev Biol 94:235-282. CrossRef Medline

Schüller U, Heine VM, Mao J, Kho AT, Dillon AK, Han YG, Huillard E, Sun T, Ligon AH, Qian Y, Ma Q, Alvarez-Buylla A, McMahon AP, Rowitch DH, Ligon KL (2008) Acquisition of granule neuron precursor identity is a critical determinant of progenitor cell competence to form Shhinduced medulloblastoma. Cancer Cell 14:123-134. CrossRef Medline

Tait SWG, Green DR (2010) Mitochondria and cell death: outer membrane 
permeabilization and beyond. Nat Rev Mol Cell Biol 11:621-632. CrossRef Medline

ter Wolbeek M, de Sonneville LM, de Vries WB, Kavelaars A, Veen S, Kornelisse RF, van Weissenbruch M, Baerts W, Liem KD, van Bel F, Heijnen CJ (2013) Early life intervention with glucocorticoids has negative effects on motor development and neuropsychological function in 14-17year-old adolescents. Psychoneuroendocrinology 38:975-986. Medline

Veis DJ, Sorenson CM, Shutter JR, Korsmeyer SJ (1993) Bcl-2-deficient mice demonstrate fulminant lymphoid apoptosis, polycystic kidneys, and hypopigmented hair. Cell 75:229-240. CrossRef Medline

Vogler M, Dinsdale D, Dyer MJ, Cohen GM (2009) Bcl-2 inhibitors: small molecules with a big impact on cancer therapy. Cell Death Differ 16:360367. CrossRef Medline

Wang VY, Rose MF, Zoghbi HY (2005) Math1 expression redefines the rhombic lip derivatives and reveals novel lineages within the brainstem and cerebellum. Neuron 48:31-43. CrossRef Medline
Wechsler-Reya RJ, Scott MP (1999) Control of neuronal precursor proliferation in the cerebellum by sonic hedgehog. Neuron 22:103-114. CrossRef Medline

Willis SN, Chen L, Dewson G, Wei A, Naik E, Fletcher JI, Adams JM, Huang DCS (2005) Proapoptotic Bak is sequestered by Mcl-1 and Bcl-xL, but not $\mathrm{Bcl}-2$, until displaced by BH3-only proteins. Genes and Development 19:1294-1305. CrossRef Medline

Wolter KG, Hsu YT, Smith CL, Nechushtan A, Xi XG, Youle RJ (1997) Movement of Bax from the cytosol to mitochondria during apoptosis. J Cell Biol 139:1281-1292. CrossRef Medline

Yang E, Zha J, Jockel J, Boise LH, Thompson CB, Korsmeyer SJ (1995) Bad, a heterodimeric partner for $\mathrm{Bcl}-\mathrm{xL}$ and $\mathrm{Bcl}-2$, displaces bax and promotes cell death. Cell 80:285-291. CrossRef Medline

Zhuo L, Theis M, Alvarez-Maya I, Brenner M, Willecke K, Messing A (2001) hGFAP-cre transgenic mice for manipulation of glial and neuronal function in vivo. Genesis 31:85-94. CrossRef Medline 